\title{
What Constitutes Successful African Enterprises? A Survey of Performance Variations in 210 African Food Processors
}

\author{
Hansen, Michael W.; Ishengoma, Esther K.; Upadhyaya, Radha
}

Document Version

Accepted author manuscript

Published in:

International Journal of Emerging Markets

DOI:

10.1108/IJoEM-03-2017-0101

Publication date:

2018

License

Unspecified

Citation for published version (APA):

Hansen, M. W., Ishengoma, E. K., \& Upadhyaya, R. (2018). What Constitutes Successful African Enterprises? A Survey of Performance Variations in 210 African Food Processors. International Journal of Emerging Markets, 13(6), 1835-1854. https://doi.org/10.1108/IJoEM-03-2017-0101

Link to publication in CBS Research Portal

\section{General rights}

Copyright and moral rights for the publications made accessible in the public portal are retained by the authors and/or other copyright owners and it is a condition of accessing publications that users recognise and abide by the legal requirements associated with these rights.

Take down policy

If you believe that this document breaches copyright please contact us (research.lib@cbs.dk) providing details, and we will remove access to the work immediately and investigate your claim. 


\title{
What Constitutes Successful African Enterprises? A Survey of Performance Variations in 210 African Food Processors
}

\author{
Michael W. Hansen, Esther K. Ishengoma, Radha Upadhyaya
}

Journal article (Accepted manuscript* ${ }^{\star}$

\section{Please cite this article as:}

Hansen, M. W., Ishengoma, E. K., \& Upadhyaya, R. (2018). What Constitutes Successful African Enterprises? A Survey of Performance Variations in 210 African Food Processors. International Journal of Emerging Markets, 136), 1835-

1854. https://doi.org/10.1108//JoEM-03-2017-0101

00l: https://doi.org/10.1108//JoEM-03-2017-0101

This article is (C) Emerald Group Publishing and permission has been granted for this version to appear here: https://research.cbs.dk/en/publications/what-constitutes-successful-african-enterprises-a-survey-of-perfo.

Emerald does not grant permission for this article to be further copied/distributed or hosted elsewhere without the express permission from Emerald Group Publishing Limited.

* This version of the article has been accepted for publication and undergone full peer review but has not been through the copyediting, typesetting, pagination and proofreading process, which may lead to differences between this version and the publisher's final version AKA Version of Record. 


\title{
What constitutes successful African enterprises?
}

\section{A survey of performance variations in 210 East African food processors}

By

\author{
Michael W. Hansen ${ }^{1}$, Esther Ishengoma², and Radha Upadhyaya ${ }^{3}$
}

\begin{abstract}
Purpose: To understand African SME performance and its antecedents is essential, both from a strategic management and an industrial development perspective. While a substantial literature on African SMEs has emerged in recent years, studies of their performance specifically are few and inconclusive. The paper addresses this lacuna in the literature by examining variations in performance of 210 East African SMEs.

Design/methodology/approach: The paper employs OLS and logistic regression and Classify k-means test to analyze performance variations in a unique data set of 210 food processing enterprises in Tanzania, Kenya, and Zambia.

Findings: Three generic types of African SMEs are identified based on performance: laggards, followers, and gazelles. The gazelles are typically medium-sized, skill-intensive companies selling relatively differentiated products in niche markets. The laggards are typically small, capital-intensive companies involved in grain milling that adopt a cost differentiation strategy. A key driver of variation in performance is found to be the quality of the external business environment (in particular the quality of intermediary markets), but also capability factors such as the strength of management. Strategy factors such as differentiation and political strategies explain performance variations.
\end{abstract}

Practical implications: Among the policy implications are that African industrial policy should focus on improving the functioning of intermediary markets, e.g. by reducing the transaction costs of inter-firm collaboration. Moreover, rather than focusing industrial policy on SMEs per se, policymakers should focus on those types of enterprises that are capable of generating high performance, e.g. skill-intensive enterprises with strong managerial capabilities, engaged in differentiation strategies.

Originality/value: The paper integrates the extant literature on African SME performance, develops an analytical framework for studying it, and presents novel empirical insights based on one of the most detailed surveys of SME performance in the continent to date. The findings have important and tangible implications for literature, as well as for industrial policy.

\section{Keywords}

Determinants of SME performance, African enterprise strategy, Industrial development policy, Food processing industry

\footnotetext{
${ }^{1}$ Hansen, Michael Wendelboe (Corresponding Author). Email: mwh.msc@cbs.dk. Copenhagen Business School, Department of Management, Society and Communication, Porcelænshaven 18b, Frederiksberg, DK 2000, Denmark ${ }^{2}$ Ishengoma, Esther. Email: esther@yahoo.com, University of Dar es Salaam Business School, Dar es Salaam, Dar es Salaam, Tanzania

${ }^{3}$ Upadhyaya, Radha. Email: radha@njora.com, University of Nairobi, Nairobi, Kenya.
} 


\section{Introduction}

The future of African development lies to a large extent in the hands of its indigenous industrial small and medium sized enterprises (SMEs). These are the enterprises that will create most of the private sector jobs that a rapidly growing labor force is craving; that will meet surging African demand for products and services; that will grow and develop skills and entrepreneurial talent; and that may become the future champions of African industry.

Much has been said about multinational corporations (MNCs) and their potential catalytic effect on development (Mol et al., 2015; Morrissey, 2012; Morris et al., 2012). But without local SME counterparts, MNCs will be exclaves, providing few spillovers to the local economy (Morrissey, 2012; Hansen, 2014). Likewise, much has been said about the developmental role of the African entrepreneur (Liedholm \& Mead, 2013; Langevang et al., 2014). But if entrepreneurs never succeed in moving beyond the start-up phase and establishing robust enterprises, their role in development will remain limited. In short, viable SMEs are and should be the backbone of African private sector development. For that reason, it is essential that academia contributes to an understanding of what makes the African Mittelstand succeed.

African SME sectors are traditionally considered as underdeveloped (Biggs et al., 2006; Hallberg, 2000). SMEs are, it is argued, disproportionally hit by the adversities of the African business environment and have difficulties gaining footholds in the economy. They are squeezed between a huge informal sector and large politically well-connected conglomerates and state-owned enterprises (SOEs). As a consequence, African industrial structures are often characterized by a 'missing middle' (Hallberg, 2000; Esuha \& Fletcher, 2002). More recently however, the literature has pointed out emerging development opportunities for the SME sector due to surging demand for goods and services, better access to capital, skilled labor and technology, and improving business environments (McKinsey, 2010; Tvedten et al., 2014; Sutton, 2012; Sutton \& Olomi 2012; ADB, 2013; Ncube et al., 2011; Chikweche \& Fletcher, 2014). In this paper, we seek to understand why some SMEs succeeds in overcoming the challenges of the African business environment and seize new growth opportunities.

Despite the importance of SMEs in African industrial development, the literature on performance of African SMEs remains embryonic (see literature review below), partly due to the historically weak development of the African SME sectors, and partly due to the relative intractability of primary data (Eunni et al., 2007). In order to fill this gap in the literature, this study examines African SME performance and its antecedents based on one of the most comprehensive surveys of SMEs in Africa: a survey of 210 food processers in Zambia, Tanzania, and Kenya measured in terms of more than 150 variables. The food 
processing industry is examined because it is by far the most important manufacturing industry across Africa; in Kenya it accounts for 40\% of manufacturing, in Tanzania 57\% and in Zambia 69\% (AfDB, 2014). Moreover, food processing has a huge catalytic effect on the overall development of Africa via its ability to link primary agricultural production with domestic, regional, and global markets.

The paper contributes to the literature by consolidating the extant literature on African enterprise performance, developing a comprehensive model for analyzing performance of African enterprises, applying this model to one of the hitherto most comprehensive surveys of African SMEs, and providing novel findings regarding the drivers of African SME performance - findings that have important and tangible implications for the continent's industrial policy.

The paper is organized as follows: first, the literature on performance of African SMEs is reviewed in order to develop an analytical model that will guide the subsequent analysis. Second, the methodology behind the study is outlined and its strengths and limitations are assessed. Third, the main findings are presented and interpreted, and the implications for industrial policy and future research are discussed.

\section{Review of the literature on performance of African enterprises}

In recent years, the literature has devoted a growing interest to African enterprise development. Much of this is informed by economics or economic geography (see e.g. Bigsten et al., 2004; Bigsten \& Söderbom, 2006; Biggs \& Shah, 2006; Fafchamps, 2004; Rodrik, 1998; Gibbon, 2005; McCormick, 1999; Altenburg \& Von Drachenfels, 2006; Hallberg, 2000; Morris et al., 2012; Morrissey, 2012; UNIDO, 2013; Page, 2013) and only rarely is a firm-level perspective applied (as argued by Ougudonto, 2007; Uchenna \& Mair, 2014; Ozcan \& Santos, 2014; Acquaah, 2012; Mellahi \& Mol, 2015; Tvedten et al., 2014). To the extent that a firm-level literature on African enterprise development exists, it tends to focus on MNCs (see e.g. Quelch \& Austin, 2012; Samuel, 2014; Kolk \& Lenfant, 2010; Hansen, 2014) or on micro and small entrepreneurial enterprises (see e.g. Kiggundu, 2002; McDade \& Spring, 2005; Liedhom \& Mead, 2013;Langevang \& Gough, 2012; Mclntyre \& Dallago 2003; Fjeldstad et al., 2006). What is notably absent in the literature is a specific focus on the sources of growth and performance of African SMEs.

The hitherto most comprehensive studies of growth and performance of African enterprises were based on the World Bank's Regional Program on Enterprise Development (RPED) survey of African manufacturing enterprises and their business environment (Biggs \& Srivastava, 1996; Bigsten et al., 2000; Fafchamps, 2004; Biggs et al., 2006). Among the findings of these studies were that failure rates of African manufacturing enterprises were very high and that most of them faced closure within the first five years 
(Marlow, 2009). Moreover, it was found that African industrial structures were characterized by a 'missing middle' with dominant large (often foreign) enterprises and a large undergrowth of small, typically informal enterprises. This 'amputated' industrial structure was partly attributed to the weak resource configurations of local enterprises (lack of human skills, managerial capability, brands, technology, and capital), and partly related to the difficult business conditions (unstable institutions, weak contractual environments, corruption, and failing supporting industries) (Biggs et al., 2006). Typically, this literature focused on either internal resource constraints or the external challenges of the business environment, but rarely analyzed the capabilities and strategies of African enterprises in overcoming these challenges (Tvedten et al., 2014; Mellahi \& Mol, 2015).

The review of the limited literature on African SMEs presented below is organized around three criteria typically identified as shaping performance - business environment factors, capability factors, and strategy factors (Tvedten et al., 2014). The review will provide a basis for developing hypotheses regarding the drivers of African SME performance that subsequently are tested.

\section{Business environment factors}

Generally, the literature focuses on three business environment factors that may affect African enterprise performance: a) institutions, ; b) infrastructure; and c) intermediaries and linkages.. We discuss each of these in turn.

\section{Institutions}

Numerous studies have found that institutional voids - including a lack of clear property rights, lack of transparency, and the inability of judicial institutions to enforce contracts - have significant adverse impact on African enterprise development and performance (see e.g. Svensson, 1998; Bohn \& Deacon, 2000; Fjeldstad et al., 2006; Charles et al., 2016). Fjeldstad et al. (2006) have argued that problems related to obtaining licenses and permits, taxation issues, and corruption are among the top impediments of SME growth in Africa. Furthermore, country level studies of Kenya and Tanzania have emphasized the negative effects of high levels of corruption and excessive regulations on SMEs (Esuha \& Fletcher, 2002; Goedhuy et al., 2008).

\section{Infrastructure}

Infrastructure is another factor often seen as seriously impairing enterprise growth in Africa (see e.g. Gelb et al., 2007; Eifert et al., 2008; Prud'homme, 2004). Ramachandran et al. (2009) found that African 
enterprises on average lose nearly $6 \%$ of value due to transport costs. Moreover, unstable energy supplies and power outages cause large losses in productivity and undermine the reliability of production (Arnold et al., 2006). A study by Eifert et al. (2008) further found that indirect costs, such as transport, energy, telecommunication, and water, accounted for a higher percentage of the total cost of manufacturing in African countries (20-30\%) than in Asian countries (13-15\%).

\section{Intermediaries and linkages}

The literature has long emphasized the importance of linkages for enterprise development in Africa (Hirschman, 1958). It has been shown that the lack of dense industrial infrastructures available upstream and downstream in value chains constrain the growth of African SMEs by undermining specialization and by making access to inputs of goods and services expensive or impossible (Esuha \& Fletcher, 2002; McCormick \& Atieno, 2002; Hansen, 2014). The absence of industrial clusters furthermore restricts SMEs' opportunities to learn through collaboration with large enterprises, and limits horizontal joint actions and spillover effects (McCormick, 1999). Country-specific case studies from Ghana and Tanzania show that the lack of co-ordination among industry players and the lack of forward linkages with larger enterprises seriously hampered SME development (Whitefield, 2002; Ishengoma, 2016).

\section{Capability factors}

The literature points to various capability factors that have shaped African enterprise performance. Among the most important are: a) technological and financial capabilities; b) human resource capabilities; and c) managerial capabilities. These capabilities are frequently proxied with size so that large enterprises typically score high on such factors while SMEs score low (Hallberg, 2000; Esuha \& Fletcher, 2002; Bigsten \& Söderblom 2006).

\section{Technological and financial capabilities}

It is widely accepted that a classical constraint on African enterprise development is a lack of capital and/or a lack of access to capital, which prevents SMEs from capturing new market opportunities and reduces prospects of survival (Gelb et al., 2007). Arnold et al. (2006) found that the lack of financial services reduced the productivity of enterprises in Southern Africa by 5 to 10 percent and that enterprises with limited access to credit and/or a high cost of financing had low productivity.

An enterprise's success and its reinforced competitive position are associated with its technological capabilities, and are improve through technical skills development, involvement in research, technology 
licensing and investment in new machinery (Lall, 1992). Hence, several studies argue that investment in new machinery and research and development is critical for enterprise growth in Africa (Ouma \& Whitefield, 2012; Oyelaran-Oyeyinka, 2006) although it is sometimes questioned whether transfer of technology from abroad impacts on SME performance (Goedhuys et al., 2008; Kragelund, 2005).

\section{Human resource capabilities}

According to the resource-based theory (Barney, 1991), human capital is key to enterprise success and competitiveness. The majority of SMEs in Africa are less likely to acquire, develop and retain highly trained employees, given their limited budgets for human resources development and the lack of appropriate business development services (Abor \& Quarteey, 2010). Moreover, educational institutions fail to produce the adequate amount of specialized skills needed by SMEs. While large enterprises will be able to develop their own training programs, SMEs will typically not be able to institute internal training, nor for that matter, pay for employees to participate in external training programs (Fening et al., 2008).

\section{Managerial capabilities}

The importance of the characteristics of owners/managers for enterprise development is noted in several studies. For instance, it has been argued that the management skills and education of owners are crucial for the performance and survival of African SMEs (Cooper \& Gimeno-Gason, 1992; Akinboade, 2015). Kuada (2007) shows that a major constraint of enterprise development in the Ghanaian example is related to limited managerial capabilities. A recent study on industrialization highlighted that differences in management practice between enterprises and countries are responsible for much of the difference in measured productivity (Newman et al., 2016).

\section{Strategy factors}

Strategy may mitigate the influence of internal and external performance contingencies (Tvedten et al., 2014). Three particular types adopted by African SMEs are discussed in the literature: a) competitive strategies; b) internationalization strategies; and c) political and network strategies.

\section{Competitive strategies}

Since the work of Porter (1981), it has been recognized that generic competitive strategies - cost, differentiation or focus (niche) strategies - are key sources of competitive advantage. However, empirical evidence on competitive strategies of African enterprises is limited. One exception is a study by AmoakoGyampah and Acquaah (2008) which examined the relationship between manufacturing strategy and 
competitive strategy and their influence on performance. This study found that competitive strategy does not directly affect performance. Instead, it was concluded that the main determinant of performance is quality orientation.

\section{Network and political strategies}

As a consequence of widespread institutional voids in Africa, some authors suggest that informal networks shape business transactions to a relatively large degree (Biggs et al., 2006). These networks are often ethnicity-based (Jackson et al., 2008; Biggs et al., 2006). Informal networks reduce transaction costs of inter-firm relations by increasing trust, reducing search, bargaining, and enforcement costs, and by moving the enforcement of contracts to an extrajudicial sphere. Moreover, such networks are used to gain access to inputs - such as capital, market intelligence, supplies, advice, etc. - that are difficult to acquire in formal markets (Fafchamps, 2001; Biggs et al., 2006). For African SMEs, political networks may be particularly important. Good political contacts are typically needed in order to gain up-to-date information on often rapidly changing business regulations (Bhattacharya \& Michael, 2008), to win government concessions (Cooksey \& Kelsall, 2011), or to be able to influence and shape regulations (Whitfield et al., 2015; Charles et al., 2016).

\section{Internationalization strategies}

The International Business literature has emphasized the importance of networks and internationalization for the success of firms in emerging markets (Elango \& Pattnaik, 2007). Studies of African internationalization have generally focused on export-based strategies. They examines whether and to what extent enterprises with high productivity are more likely to embark on export strategies (the 'selfselection' hypotheses) and whether and to what extent export strategies lead to productivity gains (see Bigsten \& Söderbom, 2006; Boermans, 2010). The literature generally finds that foreign direct investment (FDI) is limited, but when it is present it is typically intra-regional, and aimed at supporting exports (Fafchamps, 2004). SME internationalization typically takes place either to access markets or to access resources and technologies. Often such market access and resource access strategies are connected. Hence, Kuada (2007) argues that to succeed in export markets, African SMEs need to access the technology, markets and knowhow controlled by foreign firms. By fostering linkages to foreign firms on the input side ('upstream internationalization'), African SMEs' chances penetrating export markets ('downstream internationalization') are enhanced. 


\section{Analytical framework}

On the basis of this comprehensive literature review, we argue that the performance of African SMEs is driven by firms' business environment, capability, strategies, and any combination of these. This logic largely reflects the contingency approach to studies of African enterprises advocated by Tvedten et al. (2014). In the following we develop constructs and hypotheses in more detail.

\section{Performance}

The dependent variable of the study is the performance of SMEs. Among the most frequently used measures of performance are EBIT, growth of employment or turnover, employee morale, survival, market share, return on sales, return on assets, managerial performance, or IRR (Venkatraman \& Ramanujam, 1986). As performance is a multidimensional construct where different performance measures may have different antecedents as well as strengths and weaknesses, we will - in accordance with the advice of Ramsey \& Bahia (2013) and Venkatraman \& Ramanujam (1986) - employ several performance measures simultaneously.

\section{Performance drivers}

Throughout the literature, the African business environment is emphasized as a key factor in explaining the growth and performance of African enterprises. Among the most cited business environment factors are infrastructures, institutions, and inputs/linkages. As business environments can be expected to vary among the three countries studied, we expect that performance to vary depending on which country they come from, even when controlling for other factors.

H1: Performance variations can be explained with the quality of the African business environment, e.g. quality of infrastructures, institutions and intermediaries/linkages.

Enterprises with strong internal capabilities may be able to mitigate the effects of a difficult business environment. For instance, larger enterprises can be expected to be better at offsetting business environmental challenges than smaller enterprises due to their stronger financial, managerial, technological, and human resource base.

H2: Performance variations can be explained with capability factors such as size, capital, technology, and managerial capabilities. 


\section{Drivers of African enterprise performance}

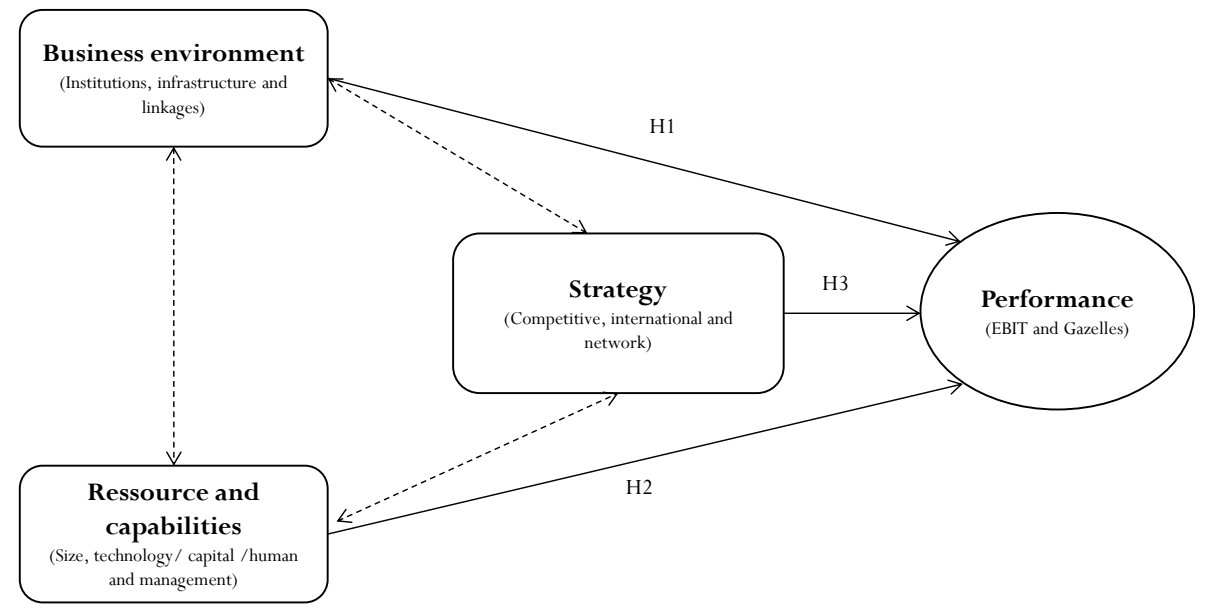

Hypotheses

H1: Performance variations can be explained with the quality of the African business environment, e.g. quality of infrastructures, institutions and intermediaries/linkages

H2: Performance variations can be explained with capability factors such as size, capital, technology, and managerial capabilities H3: Performance variations can be explained with enterprises'strategies, i.e. the extent to which they adopt competitive, network and internationalization strategies.

Figure 1: Model

SMEs react differently to similar contingencies, and therefore external and internal performance drivers may be partly modified by strategy factors. For instance, a business environment hostile to contract-based business transactions may be circumvented by network strategies, where trust within the network allows for interfirm collaboration without formal contracts. A particular form of network strategy is to foster political networks to influence the regulation and enforcement practices that the enterprise is subject to. Some enterprises may also try to improve performance by escaping the intense price competition characterizing some markets by adopting focused strategies, where they carve out niches in specific industry segments. A final strategy with potential implications for performance is the extent to which enterprises use internationalization to strengthen their competitive position and performance.

H3: Performance variations can be explained with enterprises' strategies, i.e. the extent to which they adopt competitive, network, and internationalization strategies. 


\section{Methodology}

This paper is based on a survey of food processing enterprises in Tanzania, Zambia and Kenya conducted between 2013 and 2014 to assess factors driving the success of African enterprises ${ }^{4}$. The survey was preceded by an extensive mapping phase. Due to the lack of a usable sampling frame of enterprises in the food processing industry, the main objective of the mapping phase was to identify relevant enterprises in the food processing industry in each of the countries. Research teams in each of the countries consolidated lists from various institutions for example the Kenya Bureau of Standards (KEBS) and the National Bureau of Statistics in Tanzania), combined with industry knowledge and key informant interviews. Three selection criteria were applied: enterprise age of minimum five years; total number of employees of minimum five, and having majority shareholding by citizens of the respective country. Enterprise age and the number of employees were considered as the minimum criteria of successful enterprises. The mapping exercise produced a population list of 480 enterprises in Tanzania, 100 enterprises in Zambia and 141 enterprises in Kenya. It was decided to survey all the enterprises but access to many was very difficult. In the end, 210 enterprises participated in the survey with 124 enterprises from Tanzania, 38 from Zambia and 48 from Kenya. The survey was self-administered by researchers in each of the country teams. Questions asked were related to organization and management, strategies, performance, and drivers of performance. Obviously, there are potential biases that need to be addressed when generalizing from this study. First, it is a study of only relatively successfully enterprises, defined by size and survival for at least 5 years. Hence, generalizations to all African SMEs must be made with great caution. Second, responses from less than half the relevant enterprises were obtained which could create certain biases; in particular, enterprises in remote rural areas and/or smaller SMEs are disproportionally absent from the sample.

\section{Measures}

The database has information on four performance measures: a) EBIT; b) financial performance vis-a-vis industry peers, assessed by the respondents; c) growth in turnover; and d) growth in employees. We chose to focus our analyses on EBIT, as this measure is a reflection of the reported ability of the enterprise to generate profits. In addition, we developed a performance construct using SPSS Classify K-means where

\footnotetext{
${ }^{4}$ Financial support for the field research has been provided by the Danida SAFIC project.
} 
we clustered the responding enterprises around the four above mentioned performance measures. This clustering procedure grouped the sample into three clusters:

1) The 'Gazelles' are the high performers, with high values on all four performance indicators.

2) The 'Followers' have mixed values on the performance indicators, but generally located in the middle.

3) The 'Laggards' perform below average on all performance indicators.

Table 1. Correlation matrix

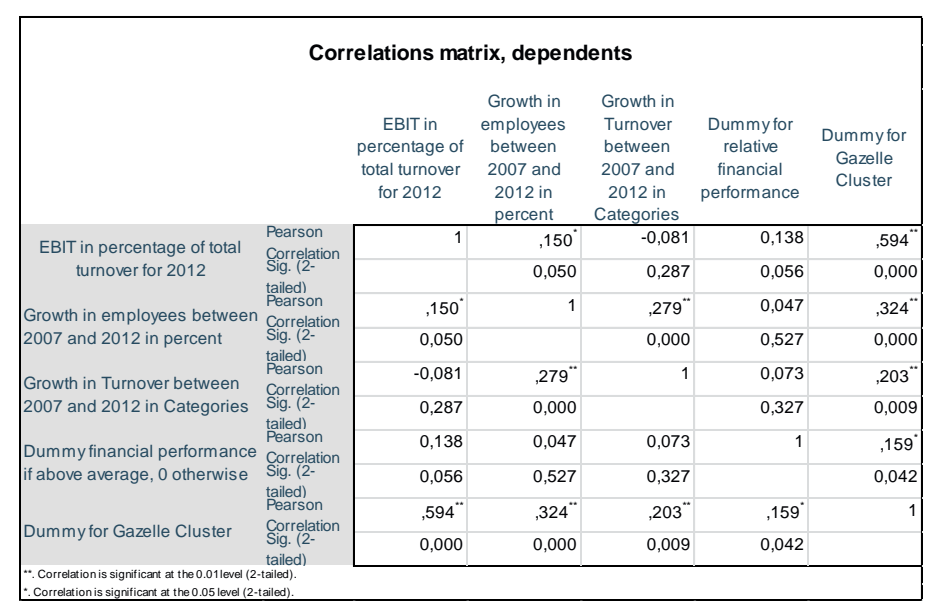

As can be seen from the correlation matrix (Table 1), the performance measures are generally correlated. A notable exception is that EBIT is not correlated with self-assessed performance, which could suggest that respondents have unrealistic self-assessments of their performance. As also observed by Akinboade (2015), employment growth is correlated with EBIT. And the aggregate performance measure 'Gazelles' is strongly correlated with the other four performance measures, suggesting that this represents the various performance measures very well.

In the subsequent analysis, we focus on two performance measures, Gazelles and EBIT, which, while strongly correlated, are distinct measures of performance. By including both measures in the analysis, we aim to get a more comprehensive picture of performance than if we had used just one, while at the same time keeping the complexity of the data analysis manageable. 
Table 2: Three countries' macro-level performance

\begin{tabular}{|c|c|c|c|c|}
\hline Indicator & Kenya & Tanzania & Zambia & Source \\
\hline $\begin{array}{ll}\text { GDP per capita, } & P P P \\
\text { (constant } & 2011 \\
\text { international \$) } & \end{array}$ & $\begin{array}{l}\text { 2009: } 2,405 \\
2014: 2,818\end{array}$ & $\begin{array}{l}\text { 2009: } 2,049 \\
2014: 2,421\end{array}$ & $\begin{array}{l}\text { 2009: } 3,061 \\
\text { 2014: } 3,725\end{array}$ & $\begin{array}{l}\text { World Bank } \\
\text { http://data.worldbank.org/indicato } \\
\text { r/NY.GDP.PCAP.PP.KD }\end{array}$ \\
\hline Average (calculated): & $\begin{array}{l}\text { 2010: } 8.4 \\
\text { 2011: } 6.1 \\
\text { 2012: } 4.6 \\
\text { 2013: } 5.7 \\
\text { 2014: } 5.3 \\
6.02\end{array}$ & $\begin{array}{l}2010: 6.4 \\
2011: 7.9 \\
2012: 5.1 \\
2013: 7.3 \\
2014: 7.0 \\
6.74\end{array}$ & $\begin{array}{l}\text { 2010: } 10.3 \\
\text { 2011: } 6.3 \\
\text { 2012: } 6.7 \\
\text { 2013: } 6.7 \\
2014: 6.0 \\
7.2\end{array}$ & $\begin{array}{l}\text { World } \\
\text { http://data.worldbank.org/indicato } \\
\text { r/NY.GDP.MKTP.KD.ZG }\end{array}$ \\
\hline $\begin{array}{l}\text { Exports of goods and } \\
\text { services (\% of GDP) }\end{array}$ & $\begin{array}{l}\text { 2009: } 20.0 \\
\text { 2014: } 16.4\end{array}$ & $\begin{array}{l}\text { 2009: } 17.4 \\
\text { 2014: } 19.5\end{array}$ & $\begin{array}{l}\text { 2009: } 29.3 \\
\text { 2014: } 40.9\end{array}$ & $\begin{array}{l}\text { World Bank } \\
\text { http://data.worldbank.org/indicato } \\
\text { r/NE.EXP.GNFS.ZS }\end{array}$ \\
\hline $\begin{array}{l}\text { Foreign } \\
\text { investment, net inflows } \\
\text { (\% of GDP) }\end{array}$ & $\begin{array}{l}\text { 2009: } 0.3 \\
\text { 2014: } 1.5\end{array}$ & $\begin{array}{l}\text { 2009: } 3.3 \\
\text { 2014: } 4.3\end{array}$ & $\begin{array}{l}\text { 2009: } 4.5 \\
\text { 2014: } 5.6\end{array}$ & $\begin{array}{l}\text { World Bank } \\
\text { http://data.worldbank.org/indicato } \\
\text { r/BX.KLT.DINV.WD.GD.ZS }\end{array}$ \\
\hline $\begin{array}{l}\text { Foreign direct } \\
\text { investment, net outflows } \\
\text { (\% of GDP) }\end{array}$ & $\begin{array}{l}\text { 2009: } 0.1 \\
\text { 2014: }-0.1\end{array}$ & $\begin{array}{l}\text { 2009: } \\
\text { 2014: } \\
\text { No data available }\end{array}$ & $\begin{array}{l}\text { 2009: } 1.8 \\
2014:-3.6\end{array}$ & $\begin{array}{l}\text { World Bank } \\
\text { http://data.worldbank.org/indicato } \\
\text { r/BM.KLT.DINV.GD.ZS }\end{array}$ \\
\hline $\begin{array}{l}\text { Manufacturing value } \\
\text { added } \\
\text { (MVA) performance }\end{array}$ & $\begin{array}{l}\text { 2005: } 1,522.5 \\
\text { 2010: } 1,882.2\end{array}$ & $\begin{array}{l}2005: 1,318.3 \\
2010: 1,991.7\end{array}$ & $\begin{array}{l}\text { 2005: } 420.4 \\
\text { 2010: } 549.8\end{array}$ & $\begin{array}{l}\text { Tanzania Industrial Competitiveness } \\
\text { Report } 2012 \\
\text { Table2, page } 25\end{array}$ \\
\hline Manufacturing/GDP & $\begin{array}{l}\text { 2007: } 14 \% \\
\text { 2014: } 11 \%\end{array}$ & $\begin{array}{l}2007: 8 \% \\
2014: 6 \%\end{array}$ & $\begin{array}{l}2007: 9 \% \\
2013: 8 \%\end{array}$ & World Bank Development Indicators \\
\hline $\begin{array}{l}\text { Ease of doing business } \\
\text { index } \\
\text { (Rank: } 1 \text { to 189) }\end{array}$ & $\begin{array}{l}\text { 2009: } 82 \\
\text { 2014: } 129 \\
\text { 2015: } 108\end{array}$ & $\begin{array}{l}\text { 2009: } 127 \\
\text { 2014: } 140 \\
\text { 2015: } 139\end{array}$ & $\begin{array}{l}\text { 2009: } 100 \\
\text { 2014: } 91 \\
\text { 2015: } 97\end{array}$ & $\begin{array}{l}\text { World Bank } \\
\text { http://data.worldbank.org/indicato } \\
\text { r/IC.BUS.EASE.XQ }\end{array}$ \\
\hline
\end{tabular}

Concerning country-level factors, we use simple country dummies to capture differences in the business environment. What these differences in business environment are can be seen in Table 2. Kenya appears to be the most advanced of the three countries we study in terms of GDP/capita, quality of business environment, and industrial development. At the other extreme, Tanzania has relatively low scores on industrialization, doing business, and GDP/capita. Zambia has relatively high growth rates and better doing business scores than the two other countries. The economy is much more internally-oriented both in terms of exports and FDI - a fact largely explained by the importance of extractive sectors. In all three countries the manufacturing sector, which is dominated by food and beverages, is infant: where manufacturing in Asian developing economies such as Vietnam or Bangladesh is $15-20 \%$ of GDP, it is around $10 \%$ in our three case countries.

Concerning capability factors, we focus on the size of enterprises, measured in terms of the log of the total number of employees in 2012, and on labor intensity, measured as the wage bill expressed as percentage of turnover. In addition, respondents were asked to rate which capabilities they perceived as the first, second, and third most important drivers of growth. Among a list of options presented to the respondents were managerial leadership, technology and machinery, capital, and human resources. 
These variables were then transformed into dummies and assigned the value 1 if respondents rated them as the first, second, or third driver of growth, and otherwise zero.

Concerning strategy factors, respondents were asked to rate the enterprises' strategies they perceived to be the first, second, or third most important behind the growth of the company. If rated, they were assigned the value of 1 , otherwise zero. The list of strategic options presented to respondents included international linkage strategy, cost focus strategy, niche strategy, and political strategy.

As food processing encompass a wide variety of industry segments with different technologies and go-tomarket strategies, it was to control for industry segment based on a distinction between grain milling, sauce-jams-and-snacks, and other (including dairy and edible oils).

\section{Analytical strategy}

Data was processed using a multiple regression procedure. The model for the regression is:

$\mathrm{P}=\mathrm{a}+\mathrm{B} \alpha_{0}+\mathrm{C} \alpha_{1}+\mathrm{S} \alpha_{2}+\varepsilon$

where $\mathrm{P}$ is a matrix of the two performance measures; $\mathrm{A}, \mathrm{B}, \mathrm{C}$, and $\mathrm{S}$ are constant, matrixes of business environment, capability, and strategy factors respectively, and $\epsilon$ is a matrix of idiosyncratic error terms. $\alpha$ 's are the coefficients to be estimated. The equations are estimated using OLS regression (in the case of the interval level EBIT variable) and logistic regression (in the case of the nominal level gazelle dummy variable). Based on the results on Variance Inflation Factor (VIF) Tolerance (see Table 4 below), there was no multicollinearity problem in the model. According to the test of heteroscedasticity using Cameron \& Trivedi's decomposition of IM-test, the variances were homogeneous, while the K-density test revealed that the residuals were normally distributed (Table 3 ).

The study is unique in several respects. It is probably the most comprehensive study of performance in African enterprises since the World Bank RPED study, providing information on dozens of enterprise capability and strategy dimensions. Contrary to most other performance studies, the study measures performance in several dimensions simultaneously, which makes more robust to interferences regarding performance. While the study only focuses on one manufacturing subsector, this is the by far most important subsector in all three countries. Of course, the database does not have panel data and instrumental variables, which is why the generalizations made are about associations, not causality. We would also have liked to examine for possible interaction effects between the independent variables (see dotted lines in Figure 1), but due to the sample size this was not statistically possible. However, when 
presenting and discussing the findings, we have made conjectures where such interaction effects may influence and qualify our findings and conclusions.

Table 3: Homoscedasticity and normality

Checking Homoscedasticity of Residuals

\begin{tabular}{|l|r|r|l|}
\hline Source & \multicolumn{1}{|c|}{ chi2 } & df & $p$ \\
\hline & & & \\
\hline Heteroskedasticity & 127.36 & 118 & 0.262 \\
\hline Skewness & 19.69 & 15 & 0.1841 \\
\hline Kurtosis & 0.26 & 1 & 0.6106 \\
\hline & & & \\
\hline Total & 147.31 & 134 & 0.2038 \\
\hline
\end{tabular}

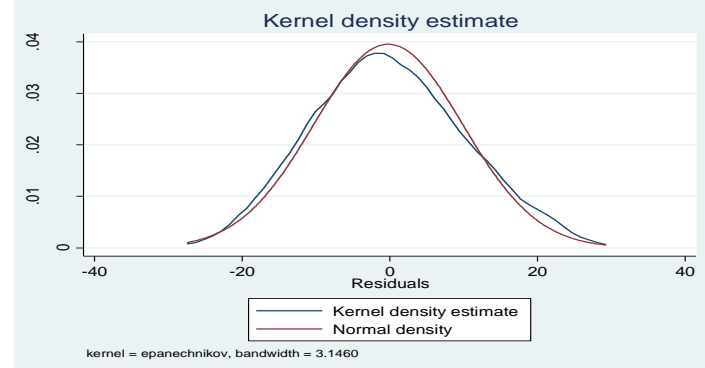




\section{Analysis}

\section{Sample description}

Of the responding enterprises, $64 \%$ were based in Tanzania, $21 \%$ in Kenya and the rest in Zambia (Table 4). Consequently, the majority of enterprises were located in the country with the relatively most difficult business environment. The most frequently cited business environment barrier to growth were costs and the availability of inputs (cited by $82 \%$ ), followed by political intervention and corruption (42\%). With respect to the industry, the majority (45\%) of firms was involved in grain milling; $15 \%$ were involved in sauce, jams, and snacks; the rest were in edible oil, dairy, and others.

With respect to the capabilities behind the success of food processors, the majority of enterprises ranked managerial capabilities (78\%) and product and market development (63\%) as the main capabilities behind their success. Access to capital and the application of technology and machinery were ranked by few enterprises.

In terms of strategies, the majority of enterprises (80\%) had adopted a focus strategy. This could enable them to compete with cheaply imported foodstuffs and expand their market, which is relatively dominated by low-income earners. However, apart from cost focus strategy, sample enterprises also seemed to focus on niche markets in order to succeed. Relatively few enterprises (37\%) indicated international linkages as the strategy behind their success, and even fewer (9\%) indicated political strategy as the factor behind success.

In terms of performance, it was found that the EBIT of the sample enterprises was quite high, on average $18 \%$ in 2012 . In comparison, in the US the average industry EBIT was $16 \%$ the same year and $7 \%$ in the food processing industry specifically. This demonstrates that African enterprises, once they are off the ground, generate high earnings. The apparent high financial performance of these firms could be explained by the fact that competition in food processing is relatively low in these markets, due to low market integration and high industry entry barriers. Another explanation could be 'adverse selection', i.e. that only activities that present the prospects of generating very high earnings will be initiated in these risky business environments with high cost of capital and high inflation.

Table 4 also reports on the composite indicator, 'gazelle', the enterprises that are high-performing on all performance measures. Here the results indicate that $36 \%$ of enterprises were gazelles while the rest were either followers or laggards. 
Table 4: Descriptive statistics

\begin{tabular}{|c|c|c|c|c|c|}
\hline Variable & $\mathbf{N}$ & Minimum & Maximum & Mean & Std. Deviation \\
\hline \multicolumn{6}{|l|}{ Country factors } \\
\hline Country Kenya & 210 & 0 & 1 & .21 & \\
\hline Country Zambia & 210 & 0 & 1 & .15 & \\
\hline Country Tanzania & 210 & 0 & 1 & .64 & \\
\hline Barrier to growth dummy: Cost/availability of input* & 209 & 0 & 1 & .82 & \\
\hline Barrier to growth dummy: Weak linkages* & 209 & 0 & 1 & .13 & \\
\hline Barrier to growth dummy: Unfair competition* & 209 & 0 & 1 & .30 & \\
\hline Barrier to growth dummy: Pol.intervention/corruption* & 209 & 0 & 1 & .42 & \\
\hline Barrier to growth dummy: Weak infrastructures* & 209 & 0 & 1 & .26 & \\
\hline \multicolumn{6}{|l|}{ Industry controls } \\
\hline Business Area Dummy Grain Milling & 192 & .00 & 1.00 & .45 & \\
\hline Business Area Dummy Sauce Jams Snacks & 192 & .00 & 1.00 & .15 & \\
\hline \multicolumn{6}{|l|}{ Capability factors } \\
\hline $\begin{array}{l}\text { Human capital Intensity in Categories - The Total wage } \\
\text { bill as \% of turnover** }\end{array}$ & 180 & 1.00 & 4.00 & 2.38 & 1.10 \\
\hline In number of employees*** & 191 & 2.30 & 7.90 & 3.88 & 1.24 \\
\hline Number of employees (permanent and casual) in 2012 & 191 & 10 & 2700 & 138 & 354.94 \\
\hline O-Advantage Dummy Human Resources & 184 & 0 & 1 & .42 & \\
\hline O-Advantage Dummy Technology and Machinery & 183 & 0 & 1 & .39 & \\
\hline O-Advantage Dummy Capital & 183 & 0 & 1 & .31 & \\
\hline O-Advantage Dummy Product and Marketing & 187 & 0 & 1 & .63 & \\
\hline O-Advantage Dummy Managerial Cap. & 187 & 0 & 1 & .78 & \\
\hline \multicolumn{6}{|l|}{ Strategy factors } \\
\hline Strategy Dummy International Linkages & 155 & 0 & 1 & .37 & \\
\hline Strategy Dummy Cost Focus & 159 & 0 & 1 & .80 & \\
\hline Strategy Dummy Niche Strategy & 157 & 0 & 1 & .59 & \\
\hline Strategy Dummy Political Strategy & 149 & .00 & 1.00 & .09 & \\
\hline \multicolumn{6}{|l|}{ Performance measures } \\
\hline Dummy for Gazelle Cluster & 163 & .00 & 1.00 & .36 & \\
\hline EBIT in percentage of total turnover for 2012 & 192 & -38.00 & 79.00 & 18.23 & 14.93 \\
\hline
\end{tabular}

* Note: Value 1 assigned if enterprises report barrier as either $1^{\text {st }}, 2^{\text {nd }}$, or $3^{\text {rd }}$ priority.

** Note: $1(1-9 \%)=28.9 \% ; 2(10-15 \%)=23.3 \% ; 3(16-29 \%)=28.3 \% ; 4(>30 \%)=19.4 \%$.

$* * *$ Note: In means natural logarithm.

\section{The drivers of performance in African SMEs}

OLS and logistic regressions were conducted to assess the overall explanatory power of the model and the ability of individual factors to explain variance when controlling for other factors in the model.

\section{The overall predictive power of the model}

As seen from the regression matrix, our model explains $37 \%$ of variation in EBIT and $22 \%$ of variation in gazelle enterprises. This means that the model is quite effective in explaining variance in performance, especially as related to EBIT. While the explained variance is satisfactory - and surely at level with or 
beyond other performance studies (for a review see Hansen \& Gwozdz, 2015) - it also suggests that there are important factors outside the model that may/can explain the performance of African SMEs, and/or that the measures employed in the survey do not adequately reflect the underlying phenomenon.

As demonstrated in the regression matrix (Table 5), the two performance measures, EBIT and the composite performance measure gazelles, produce more or less the same results in terms of which factors significantly explain variance, a finding that reassures us that we have robust findings. Hence, country, human capital intensity, management capability, niche strategy, and political strategy are consistently associated with high performance, regardless of the measure employed and when controlling for other factors.

Looking at the specific coefficients, we see that political strategies and country factors are particularly strongly associated with performance, however measured.

\section{Business environment}

As demonstrated in the regression matrix, variations in performance are significantly related to business environment factors. The fact that business environment factors - here proxied by country - are associated with performance was also the conclusion of the RPED study (see e.g. Biggs et al., 2006). Hence, we find that enterprises in Zambia have on average 13\% lower EBIT than enterprises in other regions and are $24 \%$ less likely to be gazelles - a finding that suggests that the performance of Zambian enterprises is particularly adversely affected by business environment factors. We speculate that the relatively weak performance of Zambian food processors could reflect the fact that industrial activity in this country is diverted away from domestically-oriented manufacturing sectors towards foreigndominated extractive sectors.

From the regression analysis, we do not know which specific factors related to country explain variance, as we only included country dummies. However, as seen in Table 4, costs and the availability of inputs are the main challenges for enterprises, cited by $82 \%$. Hence, it is clear that the main business environment concern for African SMEs is related to the lack of functioning intermediate markets for products and services. This observation corroborates earlier studies by Ramachandran et al. (2009), Arnold et al., (2006), Ishengoma (2016), McCormick (1999), and Hansen et al. (2014), which suggest that high input costs, lack of inputs, and lack of inter-firm linkages are the main obstacles to enterprise growth in East Africa. 
Table 5: Results of regression analysis

\begin{tabular}{|c|c|c|c|c|c|c|c|}
\hline \multirow[t]{2}{*}{ Variables } & \multicolumn{3}{|c|}{$\begin{array}{l}\text { OLS regression model for } \\
\text { EBIT }\end{array}$} & \multicolumn{4}{|c|}{ Logit model for Gazelle } \\
\hline & $\begin{array}{l}\text { Coef. (Std. } \\
\text { Err.) }\end{array}$ & $\mathrm{t} \quad \mathrm{P}>\mathrm{t}$ & $1 /$ VIF & $\begin{array}{l}\text { Coef. (Std. } \\
\text { Err.) }\end{array}$ & z & $\begin{array}{l}\text { dy/dx } \\
\text { (Std. Err.) }\end{array}$ & $z$ \\
\hline \multicolumn{8}{|l|}{$\begin{array}{l}\text { Business environment } \\
\text { factors and industry }\end{array}$} \\
\hline Country Kenya (dummy) & $\begin{array}{l}-2.330 \\
(2.091) \\
\end{array}$ & -1.11 & 0.706 & $\begin{array}{l}0.200 \\
(0.495) \\
\end{array}$ & 0.4 & $\begin{array}{l}0.0339 \\
(0.086) \\
\end{array}$ & 0.39 \\
\hline Country Zambia (dummy) & $\begin{array}{l}-13.029 * * * \\
(2.162)\end{array}$ & -6.03 & 0.803 & $\begin{array}{l}-2.271 * * \\
(0.948) \\
\end{array}$ & -2.4 & $\begin{array}{r}-0.236 * * * \\
(0.053) \\
\end{array}$ & -4.48 \\
\hline $\begin{array}{l}\text { Business area Grain milling } \\
\text { (dummy) }\end{array}$ & $\begin{array}{l}1.433 \\
(1.705) \\
\end{array}$ & 0.84 & 0.738 & $\begin{array}{l}-0.093 \\
(0.458) \\
\end{array}$ & -0.2 & $\begin{array}{r}-0.015 \\
(0.075) \\
\end{array}$ & -0.21 \\
\hline $\begin{array}{l}\text { Business area Sauce, jams, } \\
\text { snacks (dummy) }\end{array}$ & $\begin{array}{l}3.631 \\
(2.448) \\
\end{array}$ & 1.48 & 0.675 & $\begin{array}{l}0.879 \\
(0.590) \\
\end{array}$ & 1.49 & $\begin{array}{r}0.168 \\
(0.128) \\
\end{array}$ & 1.31 \\
\hline \multicolumn{8}{|l|}{ Capability factors } \\
\hline $\begin{array}{l}\text { The total wage bill as \% of } \\
\text { turnover }\end{array}$ & $\begin{array}{l}3.081^{* * *} \\
(0.776) \\
\end{array}$ & 3.97 & 0.800 & $\begin{array}{l}0.458^{* *} \\
(0.201) \\
\end{array}$ & 2.28 & $\begin{array}{r}0.075^{* *} \\
(0.032) \\
\end{array}$ & 2.33 \\
\hline Number of employees & $\begin{array}{l}0.980 \\
(0.692)\end{array}$ & 1.42 & 0.686 & $\begin{array}{l}-0.015 \\
(0.172)\end{array}$ & -0.09 & $\begin{array}{r}-0.002 \\
(0.028) \\
\end{array}$ & -0.09 \\
\hline $\begin{array}{l}\text { Human resource } \\
\text { advantages (dummy) }\end{array}$ & $\begin{array}{l}2.259 \\
(1.684) \\
\end{array}$ & 1.34 & 0.772 & $\begin{array}{l}0.830^{* *} \\
(0.419) \\
\end{array}$ & 1.98 & $\begin{array}{r}0.141^{* *} \\
(0.075) \\
\end{array}$ & 1.9 \\
\hline $\begin{array}{l}\text { Technology and machinery } \\
\text { advantages (dummy) }\end{array}$ & $\begin{array}{l}2.117 \\
(1.749) \\
\end{array}$ & 1.21 & 0.731 & $\begin{array}{l}-0.269 \\
(0.464) \\
\end{array}$ & -0.58 & $\begin{array}{r}-0.043 \\
(0.073) \\
\end{array}$ & -0.59 \\
\hline $\begin{array}{l}\text { Capital advantages } \\
\text { (dummy) }\end{array}$ & $\begin{array}{l}2.592 \\
(1.842)\end{array}$ & 1.41 & 0.775 & $\begin{array}{l}0.044 \\
(0.473) \\
\end{array}$ & 0.09 & $\begin{array}{r}0.007 \\
(0.079) \\
\end{array}$ & 0.09 \\
\hline $\begin{array}{l}\text { Product and marketing } \\
\text { advantages (dummy) }\end{array}$ & $\begin{array}{l}1.561 \\
(1.634) \\
\end{array}$ & 0.96 & 0.842 & $\begin{array}{l}-0.369 \\
(0.435) \\
\end{array}$ & -0.85 & $\begin{array}{r}-0.062 \\
(0.074) \\
\end{array}$ & -0.84 \\
\hline $\begin{array}{l}\text { Dynamic capabilities } \\
\text { advantages (dummy) }\end{array}$ & $\begin{array}{l}4.851^{* *} \\
(1.984) \\
\end{array}$ & 2.44 & 0.708 & $\begin{array}{l}0.920^{*} \\
(0.530) \\
\end{array}$ & 1.74 & $\begin{array}{r}0.131^{* *} \\
(0.067) \\
\end{array}$ & 1.97 \\
\hline \multicolumn{8}{|l|}{ Strategy factors } \\
\hline $\begin{array}{l}\text { International linkage } \\
\text { strategy (dummy) }\end{array}$ & $\begin{array}{l}3.503 * * \\
(1.784) \\
\end{array}$ & 1.96 & 0.771 & $\begin{array}{l}0.576 \\
(0.458) \\
\end{array}$ & 1.26 & $\begin{array}{r}0.100 \\
(0.083) \\
\end{array}$ & 1.2 \\
\hline $\begin{array}{l}\text { Cost focus strategy } \\
\text { (dummy) }\end{array}$ & $\begin{array}{l}1.170 \\
(1.771) \\
\end{array}$ & 0.66 & 0.758 & $\begin{array}{l}0.336 \\
(0.485) \\
\end{array}$ & 0.69 & $\begin{array}{r}0.053 \\
(0.074) \\
\end{array}$ & 0.72 \\
\hline Niche strategy (dummy) & $\begin{array}{l}5.809 * * * \\
(1.697) \\
\end{array}$ & 3.42 & 0.742 & $\begin{array}{l}0.848 * * \\
(0.436) \\
\end{array}$ & 1.94 & $\begin{array}{r}0.141^{* *} \\
(0.073) \\
\end{array}$ & 1.94 \\
\hline Political strategy (dummy) & $\begin{array}{l}15.333^{* * *} \\
(3.070)\end{array}$ & 4.99 & 0.925 & $\begin{array}{l}2.813 * * * \\
(0.805)\end{array}$ & 3.49 & $\begin{array}{r}0.605^{* * *} \\
(0.134) \\
\end{array}$ & 4.53 \\
\hline _cons & $\begin{array}{l}-4.958 \\
(4.010)\end{array}$ & -1.24 & & $\begin{array}{l}-3.810^{* * *} \\
(1.141)\end{array}$ & -3.34 & & \\
\hline Prob $>F$ & 0.000 & & & & & & \\
\hline Adj $R$-squared & 0.370 & & & & & & \\
\hline LR chi2(15) & & & & 51.480 & & & \\
\hline Prob > chi2 & & & & 0.000 & & & \\
\hline Pseudo R2 & & & & 0.219 & & & \\
\hline $\begin{array}{ll}\text { - } & \text { Note: } * * *, * * \text { and } * \text { imply } \\
\text { estimates } \\
\text { - } \quad \text { Marginal effect after Logit }\end{array}$ & $\begin{array}{l}\text { snificant at }</=0 \\
=\operatorname{Pr}(\text { gazelles })=\end{array}$ & $1,</=0$. & & pectively. Fig & & $\mathrm{s}$ are stand & \\
\hline
\end{tabular}




\section{Capabilities}

Managerial capabilities strongly explain the variation in performance as measured through EBIT. This finding corroborates several studies that emphasize the decisive role of managerial capabilities in the survival and growth of African enterprises (Cooper \& Gimeno-Gascon, 1992; Akinboade, 2015; Kuada (2007); Newman et al., 2016).

While several studies have suggested that technological resources (Ouma \& Whitefield, 2012; OyelaranOyeyinka, 2006), human resources (Abor \& Quarteey, 2010; Fening et al., 2008) or financial capabilities (Gelb et al., 2007; Arnold et al. 2006) are key determinants of performance of African enterprises, our study concluded that although such factors were cited as important by many respondents, they could not explain the variations in performance to a significant extent when controlling for other factors in the model.

The regression analysis suggests that the main capability factor interacting with variation in performance is wages relative to turnover (labor intensity): a 1 percent increase in labor intensity increases the likelihood of being a gazelle by $8 \%$ and EBIT performance 3 percent. The strong influence of this factor may reflect that enterprises with many highly paid employees (i.e. skills-intensive enterprises) are better positioned to command a premium in the market, thus enhancing performance.

The literature generally predicts that firm size is a strong predictor of performance in African contexts (Hallberg, 2000; Esuha \& Fletcher, 2002), and that in particular SMEs will have problems surviving and growing. However, in this study, size (measured in terms of number of employees) as such does not appear to be a strong predictor of performance when controlling for other factors. Bigsten \& Söderblom (2006) report similar findings from the RPED studies. This finding suggests that it may be problematic to analyze SMEs as a homogenous group in relation to performance.

\section{Strategy factors}

Among the strategy factors, political strategies were especially strongly associated with variation in performance (both EBIT and gazelles). Hence, the relatively few enterprises reporting that they adopt political strategies are $60 \%$ more likely to be gazelles than lower performing enteprises, and enterprises adopting political strategies have on average $15 \%$ better EBIT performance. This is a notable finding and could suggest that enterprises that are able to foster contacts within the political system are rewarded with higher performance. This corroborates other studies that have suggested that political networks are important for enterprise success in Africa (Bhattacharya \& Michael, 2008; Cooksey \& Kelsall, 2011; Whitfield et al., 2015; Charles et al., 2016). 
Enterprises adopting international linkage strategies generally had better EBIT performance than companies that did not have such linkages, a finding that corroborates several studies emphasizing the role of international collaboration and linkages for SME performance and growth (Kuada, 2007; Hansen, 2014). However, it should be noted that causality cannot be implied: international linkages may be disproportionally fostered by high performing enterprises.

Finally, it was found that niche strategies were consistently positively correlated with performance. This is in contrast to Amoako-Gyampah and Acquaah (2008), who did not find a role for competitive strategies. In combination with the observation that wage-intensive enterprises have higher performance and that grain milling enterprises are negatively correlated with being gazelles while snacks/sauce/jams enterprises have a positive correlation, it can be concluded that enterprises operating in wage-intensive niche markets with high demands on marketing and distribution - such as snacks/sauce/jams - have better performance than enterprises - such as grain milling - operating in capital-intensive markets producing products with commodity features.

\section{Discussion and implications}

Our study provides unique and - given the breadth and depth of the study - quite robust insights into the determinants of successful African enterprises. The paper progresses significantly a literature that is otherwise still embryonic when it comes to strategic and managerial factors behind company performance. It may have important implications for literature and industrial policy. Some of these implications are discussed in more detail below.

With average EBIT around 18\%, it is evident that the sample of 210 African food processing enterprises are on average capable of performing very well and definitely better than the average food processing enterprise in industrialized countries. The high performance suggests that difficult business environments and resource constraints do not destine African enterprises to stay stuck in low value-added, low performance trajectories. While the observed high performance may be partly influenced by adverse selection (African enterprises need extraordinarily high profits to compensate for the greater risks and costs of capital), our study nevertheless suggests that there are significant opportunities to develop successful manufacturing activities in these countries. In particular, the enterprises that were labeled gazelles were interesting: they were able to score highly on several performance dimensions simultaneously, such as EBIT and employment and turnover growth. Knowing more about what drives these highly successful enterprises may have important implications for industrial policy in Africa. 
The paper revealed a number of insights into why some enterprises may produce high EBIT and become gazelles while others don't. The typical expectation of the literature (see e.g. Svensson, 1998; Bohn \& Deacon, 2000; Fjeldstad et al., 2006; Charles et al., 2016) is that African enterprise performance is strongly associated with the business environment $(\mathrm{H} 1)$-. Supporting this hypothesis, our study found that country variations were indeed a strong predictor of variation in EBIT and gazelles, even when controlling for other factors. Hence, Zambian enterprises consistently displayed lower performance than other enterprises. The study suggested that the business environment factors affecting performance adversely were related to costs and the availability of inputs. From an industrial policy perspective, this suggests that SME development measures should focus on improving the functioning of intermediary markets and inter-firm linkages. This would imply initiatives aimed at both of making available inputs such as supplies, capital, technology and services, and reducing the transaction costs of contractual relations (linkages) between enterprises (Hansen, 2014). Another business environment factor cited by respondents as inhibiting performance was corruption and political interference in business. In terms of industrial policy this implies that efforts should be undertaken to improve market-supporting institutions and governance of the private sector.

In line with several studies (see e.g. Gelb et al., 2007; Ouma \& Whitefield, 2012; Oyelaran-Oyeyinka, 2006; Akinboade, 2015; and Kuada, 2007), the statistical analysis suggested that also capability factors are relatively strongly associated with variance in performance $(\mathrm{H} 2)$. What stands out as a key capability in our study is managerial capabilities specifically. That these capabilities are decisive is somewhat surprising as the literature typically points to capital and technology advantages as the main performance determinants (see e.g. Gelb et al. (2007) or Ouma \& Whitefield (2012). Our interpretation of why managerial factors is cited as a main capability factor is that managerial discretion and foresight are key to navigate the rapidly changing and constantly challenging African business environments. The implications for industrial policy are important: instead of building superior technological or financial capabilities in African enterprises, focus should be on assisting them in developing the managerial skills that allow them to adjust to rapidly changing and difficult business environments. This could, for instance, be achieved by fostering an entrepreneurial culture, intensifying on-the-job training of managers, and strengthening management training and education in general.

Another key capability factor identified by the study was wage intensity where it was found that enterprises that have a high wage bill relative to turnover were performing better than capital intensive enterprises. This could suggest that developing human resources and moving towards more skill intensive 
production (e.g. focusing on activities with high intensity of marketing and service or R\&D skills) is the way forward to create high performance.

In line with several studies (see e.g. Elango \& Pattnaik, 2007; Biggs et al.,2006; or Fafchamps, 2004), the paper hypothesized that strategy factors may influence performance, irrespective of capability and business environment factors (H3). . Corroborating this hypothesis, we found that political strategies e.g. seeking influence on new regulations and fostering network relations to the political system - albeit only pursued by few enterprises, was exceptionally strongly correlated with high EBIT performance and gazelle enterprises. This is a notable finding, suggesting that enterprise strategies aimed at aligning with political interests are highly rewarded in African business environments, at least until now. The implications for industrial policy are mixed. While it may have been advisable for companies to embark on political strategies to survive until now, it can be debated whether enterprises with ability to connect to the political system should be rewarded as these may not necessarily be the most efficient or productive enterprises and as successful political strategies of individual enterprises may come at huge costs to consumers, competitors and taxpayers. Moreover, even if political strategies may have been successful in the particular political economies of past private sector development in these countries, they may not be successful in the current or future political economies.

Overall, we observe that the size of the company, measured in terms of number of employees, was not a good predictor of performance. This suggests that private sector intervention and industrial policy instead of focusing on SMEs per se (Hallberg, 2000) - should focus and select enterprises based on characteristics other than size, e.g. specific management capabilities or strategic orientation. Whether this suggests that policy should focus on further facilitating the kinds of enterprises that have a proven high performance track record (e.g. enterprises with strong managerial capabilities adopting niche strategies and/or fostering international linkages) or on upgrading enterprises that are weak on these dimensions (e.g. capital-intensive enterprises with weak linkages adopting cost differentiation strategies) cannot be decided based on the evidence of this paper; this would require a detailed analysis of the cost and benefits of public investments in laggards versus public investments in gazelles.

This study has given a preliminary impression of which factors are more important than others and their relative importance in regard to enterprise performance, thus bringing the extant literature a large step forward. But there are limitations of the study that could be addressed by future research. First, while this study has generated knowledge about which factors are correlated with enterprise performance when controlling for other factors, we still know little about how the various factors interact to explain 
performance. Are there for instance specific combinations of strategy and capability factors that are particularly conducive to high performance in certain business environments? Future research should focus more on potential interaction effects which would require larger data sets than the one available for this study. Second, while this study has produced evidence of correlation, it has not produced evidence of causality. Future research on African enterprise performance should seek to build evidence of causality, e.g. by generating time series data or by conducting detailed case studies of performance trajectories of African enterprises. Third, this study has focused exclusively on those enterprises that to a higher or lesser extent have succeeded.. While this focus generates valuable information about drivers of success, it obviously does not provide insights into what causes low performance, insights that from a management and policy perspective would be equally valuable.

\section{Conclusions}

Understanding whether and how SMEs evolve into profitable and growing enterprises is crucial to informing African industrial policy and management practice. The findings of this study of food processing SMEs provide new and important insights into African SME performance and its antecedents. Based on a unique data set of 210 food processing enterprises in Tanzania, Kenya and Zambia, we examined variations in performance of African SMEs and analyzed the causes of these variations. Based on a review of the extant literature on the performance of African enterprises to date, we developed a model for analyzing performance variations. Essentially, it was hypothesized that performance is associated with business environment, capability, and strategy factors.

The paper found that the sample of successful African SMEs were, on average, relatively profitable. However, there were large variations in performance, beyond the benchmark that all the selected firms had survived for at least five years. Through a cluster analysis, three generic types of SMEs were identified: laggards, followers, and gazelles. The gazelles were typically medium-sized, skill-intensive enterprises engaged in the production and sales of relatively processed products. The laggards were typically small capital-intensive enterprises involved in grain milling, adopting a cost focus strategy. Through a regression analysis, it was suggested that performance was strongly correlated with country, which would suggest that the quality of the business environment is crucial to the performance of African SMEs. The key business environment factors related to the availability and costs of inputs and corruption/political 
interference. We found that those enterprises embarking on political strategies have significantly better performance than those that do not, indicating that in the difficult African business environment, political alignment -for better or worse - is essential to enterprise growth and profitability. Also, international linkages seem to be positively correlated with performance, which suggests that international linkage promotion should be a key ingredient in SME development policy. Finally, we found that managerial capabilities were strongly correlated with performance, a finding suggesting that the future promotion of African SME sectors should emphasize management training and development.

\section{Literature}

Acquaah, M. (2012), "Social networking relationships, firm-specific managerial experience and firm performance in a transition economy: A comparative analysis of family owned and nonfamily firms." Strategic Management Journal 33.10 (2012): 1215-1228.

Abor, J. \& Quartey, P. (2010). Issues in SME Development in Ghana and South Africa. International Research Journal of Finance and Economics, Issue 39, 218-228.

AfDB (2011). Africa competitiveness report 2011. Tunis: The African Development Bank

African Development Bank (ADB) \& Republic of Kenya (2013). The State of Kenya's Private Sector. Nairobi: Government of Kenya.

Altenburg, T., \& Von Drachenfels, C. (2006). The 'New Minimalist Approach' to Private-Sector Development: A Critical Assessment. Development Policy Review, 24(4), 387-411.

Amoako-Gyampah, K. \& Acquaah, M. (2008). Manufacturing strategy, competitive strategy and firm performance: An empirical study in developing economy environment. International Journal of Production Economy, 111(2), 575592

Arnold, J. E. M., Köhlin, G. \& Persson R. (2006). Woodfuels, livelihoods, and policy interventions: changing perspectives. World Development, 34(3), 596-611.

Barney, J. (1991). Firm Resources and Sustained Competitive Advantage. Journal of Management, 17 (1; 1), $99 ; 99-$ $120 ; 120$.

Bhattacharya, A.K. and Michael, D.C. (2008), How Local Companies Keep Multinationals at Bay, Harvard Business Review, 86(3), pp.84-95.

Biggs, T.\& Srivastava, P. (1996). Structural Aspects of Manufacturing in Sub-Saharan Africa: Findings from a Seven Country Enterprise Survey. World Bank Discussion Paper No. 346. Africa Technical Department, World Bank, Washington, DC.

Biggs, T., \& Shah, M. K. (2006). African small and medium enterprises, networks, and manufacturing performance. World Bank policy research working paper 3855.

Bigsten, A., \&Söderbom, M. (2006). What have we learned from a decade of manufacturing enterprise surveys in Africa?.The World Bank Research Observer, 21(2), 241-265.

Bigsten, A., Collier, P., Dercon, P., Fafchamps, M., Gauthier, B., Gunning, J., Isaksson, J., Oduro, A.,Oostendorp, R., Patillo, C., Soderbom, M., Teal, F., Zeufack, A. (2000). Contract flexibility and dispute resolution in African manufacturing. Journal of Development Studies 36(4), 1-37. 
Bigsten, A., Collier, P., Dercon, S. Fafchamps, M. Gauthier, B., Gunning, J. W., Oduro, A., Oostendorp, R., Pattillo, C., Söderbom, M., Teal, F. \& Zeufack, A. (2004). Do African manufacturing firms learn from exporting? Journal of development studies 40(3), 115-141.

Boermans, M. A. (2010). Learning-by-exporting and destination effects: Evidence from African SMEs. March 21.

Bohn, H. \& Deacon, R. T. (2000). Ownership Risk, Investment, and the Use of Natural Resources. The American Economic Review, 90(3), 526-549.

Charles, G., Jeppesen, S. Kamau, P. \& Kragelund, P. (2016). Firm-level Perspectives on State-Business Relations in Africa: The Food-processing Sector in Kenya, Tanzania and Zambia. Forum for Development Studies 44(1), $109-131$.

Chikweche, T.\&Fletcher, R. (2014). Rise of the middle of the pyramid in Africa: theoretical and practical realities for understanding middle class consumer purchase decision making. Journal of Consumer Marketing 31(1), 27-38.

Cooksey, B. \&Kelsall, T. (2011). The political economy of the investment climate in Tanzania. Africa Power and Politics Programme Background Paper, 1.

Cooper, A.C. \&Gimeno-Gason, F.J. (1992). Entrepreneurs, processes of founding and new firm performance. In; D.L. Sexton and Kasarda, J.D. (Eds.), The State of the Art of Entrepreneurship, PWS-Kent Publishing Company, Boston, p. 301-340.

Eifert, B., Gelb, A. \& Ramachandran, V. (2008). The cost of doing business in Africa: evidence from enterprise survey data. World Development, Vol. 36 No. 9, pp. 1531-1546

Elango, B. \& Pattnaik, C. (2007). Building capabilities for international operations through networks: a study of Indian firms. Journal of International Business Studies, 38(4), 541-555.

Esuha, J., \& Fletcher, D. (2002). The Invisible Middle: a Critical Review of Small Business Development and the Political Institutional Environment in Kenya. Paper for the 25th ISBA National Small Firms Conference

Eunni, R., Brush, C., Kasuganti, R. (2007), "SMEs in emerging markets - an overview", International Journal of Emerging Markets 2.2 (2007).

Fafchamps, M. (2001) The role of business networks in market development in Sub-Saharan Africa. In Aoki M, Hayami Y (Eds), Community and Market in Economic Development. Oxford University Press, pp 186-214

Fafchamps, M. (2004). Market institutions in sub-Saharan Africa: Theory and evidence. MIT Press Books, 1.

Fening, F. A., Pesakovic, G. \& Amaria, P. (2008). Relationship between quality management practices and the performance of small and medium sized enterprises in Ghana. International Journal for quality and Reliability Management, 25(7), 694-708.

Fjeldstad Odd-Helge, F., Kolstad, I. \&Nygaard, K. (2006). Bribes, taxes and regulations: business constraints for micro enterprises in Tanzania. Chr. Michelsen Institute, CMI. Working paper, p. 2.

Gelb, A. V. Ramachandaran, M. K. Shah, and G. Turner (2007) What Matters to African Firms: The Relevance of Perceptions Data. Policy Research Working Paper 4446. World Bank.

Gibbon, P. (2005). Trading down: Africa, value chains, and the global economy. Temple University Press.

Goedhuys, M., Janz, N. \&Mohnen, P. (2008). What drives productivity in Tanzanian manufacturing firms: technology or business environment? The European Journal of Development Research,.20(2), 199-218.

Hallberg, K. (2000). A market-oriented strategy for small and medium scale enterprises. Vol. 63. World Bank Publications.

Hansen, Michael W. (2014), From enclave to linkage economies? A review of the literature on linkages between extractive multinational corporations and local industry in Africa. No. 2014: 02. DIIS Working Paper, 2014.

Hansen, Michael W.; Gwozdz, Wencke (2015), What Makes MNCs Succeed in Developing Countries?: An Empirical Analysis of Subsidiary Performance. Multinational Business Review, Vol. 23, Nr. 3, 2015, s. 224-247. 
Hirschman, A. O. (1958). The strategy of economic development (Vol. 10). New Haven: Yale university Press.

Jackson, Terence, Kenneth Amaeshi, and Serap Yavuz. "Untangling African indigenous management: Multiple influences on the success of SMEs in Kenya." Journal of World Business 43.4 (2008): 400-416.

Kiggundu, M. N. (2002). Entrepreneurs and entrepreneurship in Africa: What is known and what needs to be done. Journal of developmental entrepreneurship 7(3), 239.

Kenya National Bureau of Statistics (KNBS). (2016). Micro, small and medium establishment (MSME) survey.

Kragelund, P. (2005). Building technological capabilities in Ghanaian SMEs through private sector development programmes. In Kuada, J. (ed) Internationalisation and Enterprise Development in Ghana, 217-270.

Kolk, A.\&Lenfant, F. (2010). MNC reporting on CSR and conflict in Central Africa. Journal of Business Ethics, 93(2), 241-255.

Kuada, J. (2007). Internationalisation, Regionalisation and Africa's Economic Growth Strategies. African Journal of Business and Economic Research, 2(1), 92-114.

Langevang, T. \& Gough, K. (2012). Diverging Pathways: Young Female Employment and Entrepreneurship in SubSaharan Africa. Geographical Journal, 178(3), 242-252

Lall, S. (1992). Technological capabilities and industrialization. World development, 20(2), 165-186.

Liedholm, C. E., \&Mead, D. C. (2013). Small enterprises and economic development: the dynamics of micro and small enterprises. Routledge.

Marlow, S. (2009). Challenging the 'myth' of the under-performing female entrepreneur. Enterprising Matters EMagazine, Spring.

McCormick, D- (1999). African enterprise clusters and industrialization: theory and reality." World development 27(9) (1531-1551.

McCormick D. \& R. Atieno (2002). Linkages between Small and Large Firms in the 28 Kenyan Food Processing Sector. In Van Dijk M.P. and H. Sandee (Eds.), Innovation and Small Enterprises in the Third World. Edward Edgar Publishing

McDade, B. E. \& Spring, A. (2005). Entrepreneurship and Regional Development. January 2005, 17 (1), $17-42$

McIntyre, R.J. \&Dallago, B. (eds.) (2003). Small and medium enterprises in transitional economies Basingstoke/New York: Palgrave Macmillan in association with UNU World Institute for Development Economics Research.

McKinsey (2010). Lions on the move: The progress and potential of African economies. McKinsey Global Institute.

Mellahi, K.\&Mol, M. J. (2015). Africa is just like every other place, in that it is unlike any other place. Africa Journal of Management, 1-9.

Morris, M., Kaplinsky, R. \& Kaplan, D. (2012). One thing leads to another: Promoting industrialisation by making the most of the commodity boom in sub-Saharan Africa. Lulu.com.

Morrissey, O. (2012). FDI in Sub-Saharan Africa: Few Linkages, Fewer Spillovers.European Journal of Development Research. 24(1), 26-31.

Newman, C., Page, J., Rand, J., Shimeles, A., Soderbom, M. \& Tarp, F. (2016). Made in Africa: Learning to Compete in Industry. Washington D.C.: The Brookings Institution.

Ncube M, Lufumpa C. L. \& Kayizzi-Mugerwa, S. (2011). The Middle of the Pyramid: Dynamics of the Middle Class in Africa. Market Brief, African Development Bank, April.

Okurut, F. (2008). Determinants of microenterprise performance in Uganda, The IUP Journal of Agricultural Economics, 5(1), 77-87.

Ougudonto, A. (2007). Strategic Management in African firms: a Local Perspective, Problems and Perspectives in Management, 5(1), 2007, 82-96. 
Ouma, S., \& Whitfield, L. (2012). The making and remaking of agro-industries in Africa. Journal of Development Studies, 48(3), 301-307.

Oyelaran-Oyeyinka, O. (2006). Learning to compete in African industry: Institutions and technology in development. Ashgate Publishing, Ltd.

Ozcan, P. \& Santos, F. M. (2014). The market that never was: Turf wars and failed alliances in mobile payments. Strategic Management Journal, 36(10), 1486-1512

Page, J. (2013). Should Africa industrialise? In Szirmai, A., Naude, W. \&Alcorta, L. (eds.). Pathways to Industrialization in the Twenty-first Century: New Challenges and Emerging Paradigms. UNU-WIDER Studies in Development Economics. Oxford: Oxford University Press.

Porter, M.E. (1981). The contributions of industrial organization to strategic management. Academy of management review, 6(4), 609-620.

Prud'homme, R. (2004). Infrastructure and development. Paper prepared for the ABCDE Conference, Washington D.C., May 3-5 2004.

Quelch, J. A. \& Austin, J. E. (2012). Should multinationals invest in Africa?. Image.

Ramachandran, V., A. Gelb, \& M. Kedia Shah (2009). Africa's Private Sector: What's Wrong with the Business Environment and What to Do About It. Washington, DC: Center for Global Development

Ramsey, J. R. \& Bahia, B. R. (2013). How to determine subsidiary performance based on the internationalization strategy. Journal of Management Policy and Practice, 14(1), 11-18.

Rodrik, D. (1998). Trade policy and economic performance in Sub-Saharan Africa. NBER Working Papers, No. w6562), 1-74.

Small Business Project (2004). Counting the cost of red tape for businesses in South Africa. Headline report, November.

Sutton, J. (2012). Competing in Capabilties. Oxford: Oxford University Press.

Sutton, J. \& Olomi, D. (2012). An Enterprise Map of Tanzania. London: International Growth Centre.

Svensson, J. (1998). Investment, property rights and political instability: Theory and evidence. European Economic Review, 42(7), 1317-1341

Tvedten, K., Wendelboe Hansen, M. \& Jeppesen, S. (2014). Understanding the rise of African business: in search of business perspectives on African enterprise development. African Journal of Economic and Management Studies, 5(3), 249-268.

Uchenna, U. \&Mair, J. (2014). Source and patterns of organizational defiance of formal institutions: Insights from Nollywood, the Nigerian movie industry. Strategic Entrepreneurship Journal, 8(1), 56-74.

UNIDO (2013). Industrial Development Report 2013. Vienna: United Nations Industrial Development Organization.

Venkatraman, N. \& Ramanujam, V. (1986). Measurement of Business Performance in Strategy Research: A Comparison of approaches. Academy of Management Review, 11(4), 801-814.

World Economic Forum (WEF), World Bank and the African Development Bank (2011), Africa Competitiveness Report, World Economic Forum, Geneva.

Whitfield, L., Therkildsen, O., Buur, L \& Klær, M. (2015). The Politics of African Industrial Policy: A Comparative Perspective. Cambridge: Cambridge University Press. 